conferred for distinguished research and writing in the field of international law.

Paul Trllet is a visiting post-doctoral fellow at the Mershon Center for Education in National Security, Ohio State University.

George O. Totren, University of Southern California, gave a course on Japanese government at the California State College at Los Angeles during the fall term.

S. SidNey Ulmer, University of Kentucky, has been elected vice-president of the Kentucky Conference of Political Scientists for 1966-67 and to the Executive Council of the Inter-University Consortium for Political Research for a two-year term, 1966-68.
V. STANLEY VARDYs, University of Wisconsin at Milwaukee, is on leave in Europe during 196667 on a grant from the American Council of Learned Societies.

Richard A. Watson has resumed his duties at the University of Missouri following a year at the Center for Advanced Study in the Behavorial Sciences.

Daniel Wit, Northern Illinois University, is spending 1966-67 at the Institute of Social Studies in the Hague as a Fulbright lecturer.

Francis D. Wormuth has returned to the University of Utah after a year's absence on a Fulbright-Hays grant

\title{
STAFF CHANGES
}

\section{New Appointments}

Robert Agranoff, assistant professor, Northern Illinois University.

Joseph Allman, acting assistant professor, University of Oregon; formerly of Michigan State University.

Phillip S. Althoff, instructor, Western Michigan University.

Edward L. ANaus, assistant professor, Memphis State University.

Thomas J. Anton, associate professor, University of Illinois at Chicago Circle; formerly of University of Illinois at Urbana.

Alan Arian, assistant professor, Tel Aviv University, Israel; formerly of Western Reserve University.

H. Lowell Ashman, instructor, Brigham Young University.

James Attaway, instructor, The Citadel.

William W. Axuine, assistant professor, The Ohio State University.

JoHN H. BaDgLey, joint appointment as associate professor at the Johns Hopkins School of Advanced International Studies, and the Washington Foreign Policy Research Center, January 1967.

BENJAMin R. BARBER, assigtant professor, University of Pennsylvania.
A. K. BAsU, assistant professor, University of Southern California; formerly of University of Oklahoma.

LAWRENCE W. BEER, assistant professor, University of Colorado, formerly of the University of Washington.

Lucy Behrman, lecturer, University of Pennsylvania.

Suzanne D. Berger, instructor, Harvard University.

Constantinos L. Beros, assistant professor, University of Colorado; formerly of Sonoma State College.

Wallace W. Berry, lecturer, San Jose State College.

Ruth A. Bevan, lecturer, Yeshiva University.

Seweryn Bialer, assistant professor, Columbia University.

Jefrerson M. Bishop, instructor, Texas College of Arts and Industries.

L. VAUGHN BLANKENSHIP, associate professor, State University of New York at Buffalo, formerly of University of California.

Benjamin Bock, associate professor, Texas Technological College; formerly of U. S. State Department.

Bernard L. Bray, instructor, Bradley University. 
William E. Brigman, assistant professor, Florida State University.

Henry P. Brubaker, instructor, University of Vermont.

Phicip M. Burgess, assistant professor, The Ohio State University.

JoHn H. BURNeTT, assistant professor, Texas Technological College; formerly of Georgia Tech.

Larry Caldwell, instructor, Wellesley, winter and spring terms, 1966-67.

Logan B. Campbell, instructor, Brigham Young University.

YI-chun Chang, assistant professor, University of Delaware; formerly of U. S. Department of Defense.

Yung Ping Chen, associate professor, Eastern Illinois University; formerly of University of Wisconsin/Platteville.

Cleo Cherryholmes, assistant professor, Michigan State University.

Tom In Teak Chung, assistant professor, University of Alabama; formerly of Vanderbilt University.

Michael Cody, JR., instructor, University of Arkansas.

John Coldins, instructor, Michigan State University.

William J. Crotty, assistant professor, Northwestern University.

Kenneth A. Dahlberg, assistant professor, Western Michigan University.

William T. DALY, assistant professor, University of Missouri/Kansas City.

Suzanne Duvall, assistant professor, Wisconsin State University/Whitewater.

John L. Eberhardt, Instructor, University of Nevada.

Smart A. EкPo, assistant professor, Lincoln University (Penna.)

JoHN ELLsworth, associate professor, Southern Illinois University; formerly of California State College/Hayward.

Arona E. Evans, Elizabeth Kimball Kendall professor, Wellesley College.

John R. FaUST, associate professor, Eastern Illinois University; formerly of Illinois Wesleyan College.
Wrldiam Faeney, instructor, Southern Illinois University.

Roosevelt Ferguson, instructor, University of Illinois at Chicago Circle.

GlenN W. Fisher, professor, University of Illinois.

Trowbridge H. Ford, assistant professor, University of Maine.

Donald Fouts, assistant professor, Northern Illinois University.

RICHARD FRedLUND, instructor, Southern Illinois University.

Anthony Fusaro, assistant professor, Northern Illinois University.

Gary D. Glenn, assistant professor, Northern Illinois University.

Harold Gordon, assistant professor, Colorado State University; formerly of University of Colorado.

BARRY GreenberG, instructor, Michigan State University.

Thomas H. Greene, assistant professor, Michigan State University; formerly of Bucknell University.

William E. Griffith, professor, Massachusetts Institute of Technology.

David H. Grubss, associate professor, Middle Tennessee State University; formerly director of The Tennessee State Planning Commission.

Edward W. Gude, instructor, Northwestern University.

Harold Guetzkow, Gordon Scott Fulcher Chair of Decision Making, Northwestern University.

Sami HaJJAR, instructor, University of Wyoming.

LELAND E. HaLL, instructor, Northern Illinois University.

Richard Halverson, instructor, Bloomfield College.

Roger P. Hamburg, associate professor, Marquette University.

YUNG C. Han, assistant professor, Florida State University.

ROBERT L. HARDGRAve, assistant professor, Oberlin. 
Edwin L. Harper, lecturer, Rutgers.

PaUl Harper, instructor, Hofstra University.

Jonathan Harris, assistant professor, University of Pittsburgh.

KENNETH HaRRIS, assistant professor, Wayne State University; formerly of University of Kansas.

James E. Hart, instructor, Duke University.

Frederick H. Hartanan, Chester W. Nimitz Professor of International Relations, Naval War College; formerly of University of Florida.

Martin J. Hauser, assistant professor, Florida State University.

AfaK HaYdar, assistant professor, Illinois State University, 1966-67.

Anne Renoulf Headley, assistant professor, University of North Carolina.

JAMES HeAPhey, associate professor, Graduate School of Public and International Affairs, State University of New York-Albany; formerly of University of Pittsburgh.

Martin O. Heisler, lecturer, University of Maryland.

Vrctor HJELm, assistant professor, Southern Methodist University; formerly of University of Colorado.

Roy D. Hofheinz, instructor, Harvard University.

Jerry P. Holland, instructor, West Georgia College.

Charles D. Hounsheld, professor, Tulane University; formerly of Emory University.

James C. Hsiung, lecturer, Rutgers.

Francis Hutchins, instructor, Harvard University.

Alan C. IsaAk, assistant professor, Western Michigan University.

Mrchael I. IsRael, instructor, Rutgers.

Francis W. Johnstone, instructor, Brigham Young University.

Josef Kalvoda, associate professor, Louisiana State University; formerly of University of San Diego.

Curfford KaUfman, assistant professor, University of Pennsylvania.
Natalie J. Kaufman, assistant professor, Rutgers.

Eldon G. KEnworthy, assistant professor, Cornell University; formerly of Yale University.

Frederic KIRK, JR., assistant professor, University of Vermont.

Robert L. KuIne, instructor, Wisconsin State University/Whitewater.

Jofl Larus, associate professor, New York University; formerly of Brandeis University.

Thomas C. Laughuin, assistant professor, University of Mississippi; formerly of Florida State University.

Thomas P. Lauth, instructor, Hofstra University.

Keith LEgG, instructor, University of Florida.

ROBERT G. LEH, associate professor, Illinois Wesleyan University.

Alan Leonhard, assistant professor, Louisiana State University; formerly of Southwest Missouri State College.

LAWRENCE LITTWin, assistant professor, University of New Mexico.

Milton G. Lodge, assistant professor, University of Iowa.

Hugh G. MacNiven, professor, University of Oklahoma; formerly of the University of Pittsburgh.

James M. Malloy, instructor, University of Pittsburgh.

Rodolfo Martinez, instructor, Brigham Young University.

Earleen M. McCarrick, assistant professor, University of Maryland.

Robert J. McSheA, assistant professor, Columbia.

Ruth McVeY, lecturer, Cornell University, 1966-67.

Robert Melson, assistant professor, Michigan State University.

LouIs S. MEYER, assistant professor, University of Wyoming.

Lester W. Mrlbrath, professor, SUNY at Buffalo; formerly of Northwestern University.

Abraham Miller, University of Illinois.

Robert Miller, instructor, Duke. 
Norman Miller, assistant professor, Michigan State University.

LAWRENCe B. MoHr, assistant professor, University of Michigan.

RoBert Mollan, assistant professor, Utah State University.

JAMES F. Morrison, assistant professor, University of Florida.

David Mozingo, assistant professor, Cornell University; formerly of Rand Corporation.

William D. Muller, assistant professor, Texas Technological College.

Roald Y. MYkkeltyedt, assistant professor, West Georgia College.

Charles G. Nelson, associate professor, University of Missouri.

JAMEs Nelson, associate professor, Northern Illinois University; formerly of University of Vermont.

Dale A. Neuman, assistant professor, University of Missouri/Kansas City.

MaRk NeUwell, associate professor, University of New Mexico.

William A. Nighswonger, assistant professor, Sonoma State College; formerly of American University.

Joнn K. C. OH, assistant professor, Marquette University.

Nrcholas G. ONuf, assistant professor, Georgetown University.

JoHn N. PADEN, assistant professor, Northwestern University.

Richard Payne, assistant professor, The Citadel.

Samuel J. Pernacciaro, instructor, Wisconsin State University/Whitewater.

David J. Peterson, assistant professor, State University of New York/Binghamton.

Joseph C. Prlegge, assistant professor, University of Alabama.

Joseph P. Pisciotte, instructor, University of Illinois at Chicago Circle.

Orville Poland, associate professor, Graduate School of Public and International Affairs, State University of New York-Albany; formerly of University of California-Berkeley.
David E. Powell, assistant professor, University of Maryland.

Robert V. Presthus, professor, University of Oregon; formerly of Cornell.

Francine Rabinovitz, assistant professor, University of Florida.

Gene E. Rainey, assistant professor, The Ohio State University.

Joseph Rajbansee, assistant professor, Florida State University.

NimRod Raphati, lecturer, Hebrew University, Jerusalem.

HAROLD V. RHODEs, assistant professor, University of New Mexico.

Thomas B. Ripy, JR., assistant professor, Memphis State University; formerly of Eastern Kentucky State College.

Arthur Rovine, assistant professor, Cornell University; formerly of Columbia University.

Ernest E. Rossr, assistant professor, Western Michigan University.

ROBERT L. ROTHWEILER, assistant professor, Wisconsin State University/Whitewater.

Margaret Rountree, instructor, State University of New York/Buffalo.

Mark A. Roy, assistant professor, Marywood College.

GerRy R. SACK, assistant professor, University of Rhode Island; formerly of Ball State Teachers College. 67.

Kenneth Sherrile, instructor, Oberlin, 1966-

Stephen Sloan, assistant professor, University of Oklahoma.

Brian Smith, S. J., instructor, Fordham University.

Stephen N. Smith, assistant professor, Steven F. Austin College; formerly of University of Kansas.

Ronald M. Sommer, assistant professor, Texas College of Arts and Industries.

James A. Stegenga, assistant professor, The Ohio State University.

Barry Nathan Stein, asgistant professor, Winona State College. 
Larry N. Stere, assistant professor, Florida State University.

Jimmie W. Stevens, assistant professor, University of Maryland.

Hugh M. Stevenson, instructor, Western Michigan University.

Russeld STrange, associate professor, Eastern Illinois University; formerly of the University of Illinois.

Marvin Surkin, instructor, Moravian College.

Zoltan M. Szaz, associate professor, Seton Hall University.

Eliot Tenofsky, instructor, Wisconsin State University/Whitewater.

John D. Thomas, associate professor, University of Alabama; formerly of Alabama College.

Walter Toxey, assistant professor, Louisiana State University; formerly of the University of Texas.

KURT K. TwERASER, instructor, University of Arkansas.

Paul W. van der Veur, profegsor, Northern Illinois University; formerly of the Australian National University.

John Preston Ward, assistant professor, Grand Valley State College.

Robert Wesser, assistant professor, Iowa State University.

Marshall H. Whithed, instructor, Northern Illinois University.

H. Thomas Wilson, lecturer, Rutgers.

Henry J. WIse, instructor, West Georgia College.

Ronald J. YALEM, associate professor, University of Alabama; formerly of the University of Southern California.

M. Georae Zaninovich, assistant professor, University of Oregon.

I. William Zartman, professor, New York University; formerly of the University of South Carolina.

Victor ZitTA, associate professor, University of Maryland.

\section{Visiting Appointments}

David W. Adamany, Wisconsin State Uni-
versity/Whitewater: instructor, University of Wisconsin, summer, 1966.

Shlomo Avineri, Herbrew University, Jerusalem: lecturer, Yale University, 1966-67.

John C. Bollens, UCLA: professor, University of Colorado, summer, 1966.

H. Peter Ch'en, lecturer, University of Pennsylvania, 1966-67.

Alberto Crria, University of Buenos Aires; assistant professor, University of North Carolina, 1966-67.

Hugh M. Clokır, University of California/ Berkeley: professor, University of Virginia, 196667.

E. Lewrs B. Curtis, professor, Hiram College, 1965-66, and Birmingham-Southern College, 1966-67.

Lewis A. Dexter, professor, Michigan State University, spring, 1967.

John C. Donovan, Bowdoin College: professor, Columbia University, summer, 1966.

John Ferguson, professor, Fels Institute of Local and State Government, 1966-67.

Alexander L. George, Rand Corporation: lecturer, Stanford University, winter, 1967.

Fred I. Greenstein, Wesleyan University: professor, Yale University, fall, 1966.

Douglas Hodgrin, lecturer, Bates College.

JAMES T. Jones, lecturer, University of Illinois, summer, 1966.

EDWARD LiTT, University of Wisconsin/Milwaukee: associate professor, University of California/Berkeley, 1966-67.

Noah Lucatz, Hebrew University in Jerusalem: lecturer, Glasgow University, Scotland, 1966-67.

KIt G. Machado, University of California/ Berkeley: assistant professor, University of Missouri.

Ror C. Macridis Brandeis University: professor, Fletcher School of Law and Diplomacy, spring. 1967.

Robert Meagher, Columbia University School of Law: lecturer, Fletcher School of Law and Diplomacy, fall, 1966. 
Andrew Milnor, Boston University: assistant professor, Cornell University, 1966-67.

Peter Nettl, professor, University of Pennsylvania, spring, 1967.

Nelson Polsby, Wesleyan University: lecturer, Yale University, second term, 1966-67.

URI RA'ANAN, professor, M.I.T. and Fletcher School of Law and Diplomacy, 1966-67.

Dankwart A. Rustow, Columbia University: professor, M.I.T., 1966-67.

Grovanni Sartori, University of Florence, Italy: professor, Yale University, 1966-67.

Chardes P. Schleicher, University of Oregon: professor, Indian School of International Studies, New Delhi.

JoHn Scotr, associate professor, Fletcher School of Law and Diplomacy, fall, 1966.

RoBert Shartet, University of Missouri: assistant professor, University of Wisconsin Law School, fall, 1966.

Garold W. Thumm, Bates College: professor, National War College, 1966-67.

Morris Watnick, Wayne State University: associate professor, SUNY at Binghamton, 196667.

Joseph WILkinson, associate professor, Northern Illinois University, 1966-67.

\section{Other Appointments}

Totten J. Anderson, associate dean of the Division of Social Sciences and Communications of the College of Letters, Arts and Sciences, University of Southern California.

HoYT B. Ballard, associate professor and chairman, Texas College of Arts and Industries; formerly of Oregon State University.

Charles Beall, associate professor and chairman, University of Denver; formerly of Eastern Illinois University.

George Blanksten, chairman, Northwestern University.

ARDATh W. Burks, director, International Education, Rutgers.

JAMES A. Clark, assistant to the president, University of Maine.

Dorothy I. Cline, acting director, Division of Government Research, University of New Mexico.
Edwin L. Cobs, assistant professor and chairman, Austin Peay State College; formerly of Texas $A$ and $M$ University.

Robert J. Duman, acquisitions librarian, San Jose State College.

Paul C. Dunham, research assistant, Bureau of Public Administration, University of Maine.

Joseph Dunner, chairman, Yeshiva University.

Alice L. Ebex, head, Illinois State University.

Mario Einaudi, director, Center for International Studies, Cornell University.

Neil F. Garvey, acting chairman, February: 1966-August, 1966, University of Illinois.

Harvey Glickman, ehairman and director of African Studies, Haverford College.

Morton Gorden, associate professor and research associate, Foreign Policy Research Institute, University of Pennsylvania.

LyMan JAY GoULd, chairman, University of Vermont.

SAMUEL K. Gove, professor and acting director, Institute of Government and Public Affairs, University of Illinois.

Lynwood M. Holland, professor and head, Texas Technological College, January, 1967; formerly of Emory University.

Charles B. JUdah, acting chairman, University of New Mexico.

Fred Krinsky, chairman, University of Southern California.

Martin Lichterman, professor of history and dean, Center for Humanities and Social Sciences, Union College; formerly director, New England Board of Higher Education.

Irvine W. Marsters, Jr., career development specialist, Bureau of Public Administration, University of Maine.

JoHn D. Martz, assistant director, Institute of Latin American Studies, University of North Carolina.

Eugene A. Mawhinney, acting head, University of Maine.

Timothy D. Mead, acting chairman, Moravian College, 1966-67.

Edwin B. Morrelu, chairman, Brigham Young University. 
EDWARD MUTh, associate professor and director, African Center, Lincoln University; formerly of the University of Basutoland, Bechuanaland and Swaziland.

Joseph F. Newman, assistant professor and research associate, Institute of Government Research, Florida State University.

Charles Press, chairman, Michigan State University.

Jesse W. Reeder, coordinator, International Relations program, Brigham Young University.

JoHN B. RICHARD, acting chairman, University of Wyoming.

Chester B. Rogers, assistant professor and director, Institute of Public Affairs, Western Michigan University.

Alvin Z. Rubinstein, chairman, Graduate International Relations program, University of Pennsylvania.

Royal D. Sloan, Jr., associate professor and assistant director, Bureau of Governmental Research and Service; formerly of the University of Nebraska.

Frederick C. Spiegel, associate dean, School of Business and Public Administration, University of Missouri.

Richard F. STAar, chairman, Emory University.

MatThew C. StewarT, associate director, Institute of International Studies, University of South Carolina.

Leo C. Stine, associate dean, Graduate School, Western Michigan University.

Victor A. Thompson, professor and head, University of Illinois.

MaUrice K. Townsend, professor and dean of Academic Affairs, Stanislaus State College: formerly of Moorhead State College.

GEORge M. WALKER, JR., lecturer and research associate, Institute of Public Health, University of Michigan.

EARle Wallace, acting dean, Graduate School, University of North Carolina.

ELLSWORTH E. WEAVER, acting chairman, University of Utah.

David W. Welborn, acting head, Northern Illinois University, 1966-67.

ROBERT L. WEST, professor and coordinator,
International Development Studies, Fletcher School of Law and Diplomacy; formerly of the Rockefeller Foundation.

\section{Promotions (with new rank)}

Chadwick F. Alger, Northwestern University: professor.

Hayward R. Alker, Jr., Yale University: associate professor.

Salvatore Arcilesi, The Citadel: associate professor.

James D. Atkinson, Georgetown University: professor.

Twiley W. Barker, JR., University of Chicago at Chicago Circle: professor.

Donald D. Barrx, Lehigh University: associate professor.

JohN Batchelder, University of Iowa:assistant professor.

CARL Beck, University of Pittsburgh: professor.

Theodore L. Becker, University of Hawaii: associate professor.

Goberdhan Bhagat, University of Mississippi: associate professor.

John C. Buechner, University of Colorado: associate professor.

Robert S. CAHILL, University of Hawaii: associate professor.

John W. Chapman, University of Pittsburgh: professor.

Edward F. Coore, University of Pittsburgh: professor.

RIChard W. CotTam, University of Pittsburgh; professor.

Richard Dekmejian, SUNY at Binghamton: assistant professor.

Martha A. Dertuick, Harvard University: assistant professor.

P. Allan Dionisopoulos, Northern Illinois University: professor.

Robert Dove, Iowa State University: assistant professor.

John G. Eriksen, University of Oklahoma; professor.

Donald L. Fatrchind, The Citadel: associate professor. 
Lee W. Farnsworth, Brigham Young University: associate professor.

Victor C. Ferkiss, Georgetown University: professor.

Harry J. Friedham, University of Hawaii: professor.

Robent S. Friedman, The University of Michigan; professor.

Monton J. Frisch, Northern Illinois University: professor.

Stanley T. Gabis, University of Missouri: professor.

Frederick Gareau, Florida State University: associate professor.

LYMAN JAY Gould: Univergity of Vermont: professor.

Richard B. Gray, Florida State University: professor. sor.

Andrew Hacker, Cornell University: profes-

Charles V. Hamilton, Lincoln University (Penna.): professor.

Royce Hansen, American University: professor.

Guy B. Hathorn, University of Maryland: associate professor.

Arnold J. HeIDEnheImer, University of Florida: professor.

Ray C. Hrllam, Brigham Young University: associate professor.

JERRY Hough, University of Illinois: associate professor.

Edwin C. Hoyt, University of New Mexico: professor.

Helen Ingram, University of New Mexico: assistant professor.

Kenneth Janda, Northwestern University: associate professor.

Arthur L. Kalleberg, University of Missouri: associate professor.

Henry S. Kariel, University of Hawaii: professor.

C. I. Eugene KIM, Western Michigan University: associate professor.

Richard H. Kosakr, University of Hawaii: professor.
Charles Kungman, Jr., San Joge State College: associate professor.

H. R. Mahoon, Memphis State University: associate professor.

John D. Martz, University of North Carolina: associate professor.

William T. McCraw, San Jose State College: assistant professor.

O. Ruth McQuown, University of Florida: associate professor.

Lours C. Mrdaley, Brigham Young University: associate professor.

Linda B. Millen, Barnard College/Columbia University: assistant professor.

David W. Minar, Northwestern University: professor.

Glenn G. Morgan, San Jose State College: professor.

Edwin B. Morrelt, Brigham Young University: associate professor.

Joseph S. Nye, Harvard University: assistant professor.

William V. O'Brien, Georgetown University: professor.

Nathaniel S. Preston, American University: professor.

Quentin L. Quane, Marquette University: associate professor.

William O. Reichert, Wisconsin State University/Whitewater: professor.

Fauneil J. Rinn, San Jose State College: associate professor.

William A. Ritchie, Western Michigan University: associate professor.

John H. Romani, University of Michigan: associate dean, School of Public Health.

Alvin $Z$. Rubinstein, University of Pennsylvania: professor.

Bruce M. Russe'T, Yale University: associate professor.

ANdrew M. Scotr, University of North Carolina: professor.

Robert D. Smith, Western Michigan University: assistant professor.

Richard G. Smolka, American University: associate professor. 
Peter Snow, Univergity of Iowa: agsociate professor.

Richard C. Spenchr, Coe College: professor emeritus, after 18 years at Ooe.

Douglas St. Angelo, Florida State University: associate professor.

Stoney G. Tarrow, Yale University: assistant professor.

M. LADD Thomas, Northern Illinois University: professor.

Lors E. Tonnence, American University: professor.

TaNa Tsov, University of Chicago, professor.

Kart von Vorys, University of Pennsylvania: associate professor.

Richard A. Watson, University of Missouri: professor.

David M. Welborn, Northern Illinois University: associate professor.

JAmes P. Young, State University of New York/Binghamton: associate professor and chairman.

\section{Retirements and Resignations}

Roma Sawyer Cheek, Duke University, retired at the close of the 1965-66 academic year.

Edward F. Dow has retired as head of the department of history and government after serving 34 years in that capacity at the University of Maine.

Stanley Kelley, Jr. has resigned as chairman at Princeton University and will devote full time again to teaching and research.

Karl N. Snow resigned from Brigham Young University to become Legislative Analyst with the Utah State Legislature.

Gilbert Y. Steiner, director of the Institute of Government and Public Affairs at the University of Illinois, has resigned his position to join the Brookings Institution in Washington, D. C.

Stephen B. Sweeney will retire after 30 years as director of the Fels Institute of Local and State Government. He will become director emeritus as of July 1, 1967, and Samuel S. Fels Research Professor of Governmental Administration until he retires in 1970.

Irwin Stewart, former president of the University of West Virginia (1946-58) and professor of political science at the University since 1958, will retire from active duty at the end of the 1966-67 academic year.

\section{IN MEMORIAM}

Edgar S. Furniss Jr. On August 17, 1966 death prematurely claimed Edgar S. Furniss, Jr., Mershon Professor of Political Science at the Ohio State University.

Professor Furniss was 48 years of age. He was born in Iowa in 1918; be received his Bachelor's degree from Yale in 1940 and his Ph.D. from that University in 1947. He served in the Department of State from 1944 to 1946; and in 1947 he joined the Department of Politics at Princeton University where he rose to the rank of Prefessor. In 1963 he came to Ohio State as Mershon Professor of Political Science and in that same year became first Director of the Mershon Social Science Program in National Security Studies, a post he filled with vigor and enthusiasm that spread as contagion to all those with whom he associated.

That he took special delight in his post as creator and builder of the Mershon Social Science Program there is no doubt. In contributing to the volume commemorating the twenty-fifth anni- versary of his graduating class at Yale, he wrote the following:

"At turning points in my life, I received crucial advice from two Yale Professors. Professor Nicholas Spykman . . advised me to go to Berkeley for one year . . Professor Aronld Wolfers later advised me to quit Yale for Washington and get some practical experience in how the government worked. The third bit of advice we (my wife and I) gave ourselves. After sixteen... years in Tigertown ... we told ourselves to accept the chance to enlarge our horizons, participate in building worthwhile enterprises and moved to Columbus, Ohio. I have never regretted following all three advices."

To say that his friends and colleagues at Ohio State joined him in never regretting his having followed that last advice would be an understatement that Edgar Furniss would have liked. The stronger, straightforward truth is that we delighted in his company. We admired the energy 